\title{
Increasing harvest maturity of whole-plant corn silage reduces methane emission of lactating dairy cows
}

\author{
B. Hatew, ${ }^{* 1}$ A. Bannink, $†$ H. van Laar, ${ }^{*} \ddagger$ L. H. de Jonge, ${ }^{*}$ and J. Dijkstra* \\ *Animal Nutrition Group, Wageningen University, PO Box 338, 6700 AH Wageningen, the Netherlands \\ †Animal Nutrition, Wageningen UR Livestock Research, PO Box 338, 6700AH Wageningen, the Netherlands \\ ¥Nutreco R\&D, PO Box 220, 5830 AE Boxmeer, the Netherlands
}

\begin{abstract}
The objective of this study was to investigate the effects of increasing maturity of whole-plant corn at harvest on $\mathrm{CH}_{4}$ emissions by dairy cows consuming corn silage (CS) based diets. Whole-plant corn was harvested at a very early [25\% dry matter (DM); CS25], early (28\% DM; CS28), medium (32\% DM; CS32), and late (40\% DM; CS40) stage of maturity. In a randomized block design, 28 lactating Holstein-Friesian dairy cows, of which 8 were fitted with rumen cannula, received 1 of 4 dietary treatments designated as T25, T28, T32, and T40 to reflect the DM contents at harvest. Treatments consisted of (DM basis) 75\% CS, 20\% concentrate, and $5 \%$ wheat straw. Feed intake, digestibility, milk production and composition, energy and $\mathrm{N}$ balance, and $\mathrm{CH}_{4}$ production were measured during a 5 -d period in climate respiration chambers after an adaptation to the diet for $12 \mathrm{~d}$. Corn silage starch content varied between 275 (CS25) and 385 (CS40) g/ kg of DM. Treatments did not affect DM intake (DMI), milk yield, or milk contents. In situ ruminal fractional degradation rate of starch decreased linearly from 0.098 to $0.059 / \mathrm{h}$ as maturity increased from CS25 to CS40. Apparent total-tract digestibility of DM, organic matter, crude protein, neutral detergent fiber, crude fat, starch, and gross energy (GE) decreased linearly with maturity. Treatments did not affect ruminal $\mathrm{pH}$, volatile fatty acids, and ammonia concentrations, and volatile fatty acids molar proportions. The concentration of C18:3n-3 in milk fat decreased linearly, and the concentration of C18:2n-6 and the n-6:n-3 ratio increased linearly with maturity. A quadratic response occurred for the total saturated fatty acid concentration and total monounsaturated fatty acid concentration in milk fat. Methane production relative to DMI $(21.7,23.0,21.0$, and 20.1 $\mathrm{g} / \mathrm{kg})$ and relative to GE intake $(0.063,0.067,0.063$,
\end{abstract}

Received July 1, 2015.

Accepted September 2, 2015.

${ }^{1}$ Corresponding author: bayissa.chuko@wur.nl and 0.060 MJ/MJ; values for T25, T28, T32, and T40, respectively) decreased linearly with maturity. Also, $\mathrm{CH}_{4}$ emission relative to fat- and protein-corrected milk tended to decrease linearly with maturity (13.0, $13.4,13.2$, and $12.1 \mathrm{~g} / \mathrm{kg}$ of fat- and protein-corrected milk, for T25, T28, T32, and T40, respectively). Intake of GE and metabolizable energy, and energy retained, all expressed per unit of metabolic body weight, did not differ among treatments. Nitrogen intake, $\mathrm{N}$ use efficiency (milk $\mathrm{N} / \mathrm{N}$ intake), and $\mathrm{N}$ balance were not influenced by treatments. Increasing maturity of wholeplant corn at harvest may offer an effective strategy to decrease $\mathrm{CH}_{4}$ losses with feeding $\mathrm{CS}$ without negatively affecting cow performance.

Key words: maturity, corn silage, starch, methane, dairy cow

\section{INTRODUCTION}

Whole-plant corn silage (CS) is a major forage component in dairy cattle rations in many parts of the world, with a high energy content and generally good ensiling characteristics (Khan et al., 2015). The nutritive value of CS is highly dependent on its digestibility and content of starch. Starch content of CS is mainly affected by stage of maturity of the plant at harvest (Johnson et al., 1999). The advancing maturity of the corn crop during the grain-filling period increases the content of DM and starch, and decreases the content of NDF (Tolera et al., 1998; Johnson et al., 1999; Phipps et al., 2000). In addition, the vitreousness of corn kernels (i.e., the proportion of vitreous in the total endosperm) increases with maturity (Correa et al., 2002; Ettle et al., 2001), and is associated with reduced rumen degradability of starch (Philippeau and Michalet-Doreau, 1997; Ettle et al., 2001) and an increased postruminal starch digestion (Sutton et al., 2000). A reduced ruminal fractional rate of starch degradation may lead to an improved animal performance as no associated loss of energy with $\mathrm{CH}_{4}$ production occurs (Dijkstra et al., 2011), although an advanced corn maturity leading to DM contents beyond $35 \%$ may slightly reduce milk 
production due to decreased feed intake and corn silage digestibility (Khan et al., 2015).

The importance of changes in the nutritional components of CS with increasing maturity with respect to nutritional and production responses by ruminants livestock are well documented in several studies (Cammell et al., 2000; Phipps et al., 2000; Johnson et al., 2002a). However, only limited systematic studies have evaluated the effects of harvest maturity of whole-plant corn for corn silage on $\mathrm{CH}_{4}$ emissions in lactating dairy cows, though increasing the starch content in the diet of ruminants is suggested as an effective way of decreasing $\mathrm{CH}_{4}$ emission intensity (Hristov et al., 2013). Feeding high starch diets to ruminants lowers rumen $\mathrm{pH}$ and generally favors propionate production at the expense of acetate (Bannink et al., 2008; Lettat et al., 2013) and may decrease the population of protozoa (Dijkstra, 1994; Martin et al., 2010; Morgavi et al., 2010). These effects reduce the availability of hydrogen to be used by rumen methanogens to produce $\mathrm{CH}_{4}$.

In beef cattle fed diets containing on average $77 \%$ corn silage, increasing CS maturity at harvest tended to reduce $\mathrm{CH}_{4}$ relative to feed DM and carcass gain, where $\mathrm{CH}_{4}$ emission was measured using the sulfur hexafluoride $\left(\mathrm{SF}_{6}\right)$ method and corn silage was offered ad libitum (Mc Geough et al., 2010). In contrast, Cammell et al. (2000) did not find significant differences in $\mathrm{CH}_{4}$ emission, ME intake, and in the partitioning of $\mathrm{ME}$ to heat or milk in dairy cattle fed diets based on corn silage made from whole-plant corn harvested at different stages of maturity and measured using respiration chambers. The proportion of CS in the diet was limited to $40 \%$ of the total diet DM, and the authors suggested that observed effects of maturity of corn silage at harvest would be greater with a higher inclusion of corn silage. In view of these findings and of the observed effect of maturity of corn at harvest, it is important to further evaluate the potential of advanced maturity of corn as a $\mathrm{CH}_{4}$ mitigation strategy when including a high proportion of CS in diets of lactating dairy cows.

The primary objective of this study was to evaluate the effects of increasing maturity of whole-plant corn at harvest on $\mathrm{CH}_{4}$ emission by lactating dairy cows consuming CS-based diets. We hypothesized that advancing whole-plant corn maturity at harvest increases starch content, and decreases NDF content and ruminal fractional degradation rate of NDF and starch, and thus enhances postruminal starch supply or may cause a shift in the pattern of rumen VFA production toward more propionate. These changes are expected to decrease $\mathrm{CH}_{4}$ yield $\left(\mathrm{CH}_{4}\right.$ per unit of feed intake) and $\mathrm{CH}_{4}$ emission intensity $\left(\mathrm{CH}_{4}\right.$ per unit of milk produced).

\section{MATERIALS AND METHODS}

\section{Silage Preparation}

The whole-plant CS was prepared from a single corn (Zea mays) variety (LG30218; Limagrain, Rilland, the Netherlands), which is a corn variety commonly used by farmers in the Netherlands. Corn was planted on sandy soil at a density of 100,000 seeds per ha and row spacing of $0.78 \mathrm{~m}$ at the experimental farm of Wageningen University (Achterberg, the Netherlands) in mid-May 2013. The corn field was fertilized with cattle slurry (40 t/ha) containing $3.8 \mathrm{~kg}$ of N, $1.5 \mathrm{~kg}$ of $\mathrm{P}_{2} \mathrm{O}_{5}$, and $4.8 \mathrm{~kg}$ of $\mathrm{K}_{2} \mathrm{O}$ per tonne; triple superphosphate (75 kg/ha) and calcium ammonium nitrate (125 kg/ ha). The whole-plant corn was harvested and ensiled at a very early $(25.1 \%$ DM, harvested on September 20; CS25), early (27.7\% DM, harvested on September 28; CS28), medium (32.0\% DM, harvested on October 9; CS32), and late (40.3\% DM, harvested on October 31; CS40) stage of maturity. To determine the stage of maturity at harvest, 5 corn plants were randomly selected throughout the field once weekly, harvested, chopped, and dried at $60^{\circ} \mathrm{C}$ in a forced-air oven at least for $48 \mathrm{~h}$. Once the DM content aimed was attained, the whole corn plants were harvested with a precision chop harvester (Claas Jaguar 980 with a 6-row corn head) with chop length and cutting height set to 7 and $120 \mathrm{~mm}$, respectively, and kernel processer set to $1 \mathrm{~mm}$ to ensure that all kernels were sufficiently crushed or processed.

Immediately after harvest, tractor-trailers with the harvested plant materials were weighed and unloaded into one-side walled concrete short silos (13.8 m long, $2.9 \mathrm{~m}$ wide, and $0.6 \mathrm{~m}$ high) for CS25, CS28, and CS32, and a long silo $(40.0 \mathrm{~m}$ long, $2.5 \mathrm{~m}$ wide, and $0.8 \mathrm{~m}$ high) for CS40. A long silo was used to be able keep the package density similar among different harvest maturity because compaction is more difficult when DM content is higher. The silage heaps were mechanically compacted with a heavy weight tractor and a loader. After the silos were filled and compacted, the sides and top of the silage heap was covered with 2 layers of 0.15 $\mathrm{mm}$ black polyethylene plastic sheet. To minimize the damage to the polyethylene sheet, the plastic sheet was further covered with a knitted protection sheet, and sand was placed on the top of the sheet to ensure effective air tight sealing. Ensiling was done without addition of inoculum and completed within approximately $3 \mathrm{~h}$ of harvest at the field.

To evaluate the fermentation characteristics and DM content of the silages before the animal feeding experiment, samples using a hollow drill were taken on d 110, 
102, 91, and 69 after ensiling for CS25, CS28, CS32, and CS40, respectively.

\section{Experimental Design, Feeds, and Feeding}

The experiment was conducted at the Animal Research Facilities of Wageningen University, Wageningen, the Netherlands, during April to May 2014. All experimental procedures were approved by the institutional Animal Care and Use Committee of Wageningen University (Wageningen, the Netherlands) and carried out under the Dutch law on animal experimentation.

Twenty-eight Holstein-Friesian dairy cows (8 primiparous and 20 multiparous) of which 8 were fitted with a permanent rumen cannula $(10 \mathrm{~cm}$ i.d., Type 1C, Bar Diamond Inc., Parma, ID) were allocated to 7 blocks of 4 cows each, based on parity, DIM (103 \pm $18.4 \mathrm{~d}$; mean $\pm \mathrm{SD})$, and fat- and protein-corrected milk $($ FPCM; $38.0 \pm 9.0 \mathrm{~kg} / \mathrm{d})$ at the start of the trial, and presence of a rumen cannula, with FPCM calculated as $[0.337+0.0116 \times$ fat $(\mathrm{g} / \mathrm{kg})+0.0060$ $\times$ protein $(\mathrm{g} / \mathrm{kg}$ of milk) $\times$ milk yield $(\mathrm{kg} / \mathrm{d})(\mathrm{CVB}$, 2008). Cows within blocks were randomly assigned to 1 of 4 experimental treatments that consisted of (DM basis) $75 \%$ CS, $20 \%$ concentrate, and $5 \%$ wheat straw. Treatments were designated as T25, T28, T32, and
T40 to reflect the DM contents of whole-plant corn at harvest (CS25, CS28, CS32, and C40, respectively). The CS were used for in situ incubation, whereas the animal performance and $\mathrm{CH}_{4}$ production were based on the treatments. Concentrate and wheat straw were similar for all treatments. Concentrate was produced at Research Diet Services (RDS BV, Wijk Bij Duurstede, the Netherlands) in one batch and hence expected to be of uniform composition throughout the experiment. The concentrate was composed of $(\mathrm{g} / \mathrm{kg}$ of DM) soybean meal $(47 \% \mathrm{CP})=327$, formaldehyde-treated soybean meal $($ RUMI-S $)=275$, corn $=255$, rapeseed meal $=$ 52 , limestone $=31$, urea $=20$, sodium chloride $=15$, mono-calcium phosphate $=12$, magnesium oxide $=11$, chromium oxide $=1.5$, and vitamin-mineral premix $=$ 2.0. The analyzed chemical composition of the concentrate was ash $=109, \mathrm{CP}=403, \mathrm{NDF}=127, \mathrm{ADF}=$ $67, \mathrm{ADL}=7$, crude fat $=27$, and starch $=183$ (all in $\mathrm{g} / \mathrm{kg}$ of DM), and gross energy $(\mathbf{G E})=17.8 \mathrm{MJ} / \mathrm{kg}$ of DM. Similarly, the wheat straw consisted of ash $=107$, $\mathrm{CP}=31, \mathrm{NDF}=758, \mathrm{ADF}=475, \mathrm{ADL}=61$, crude fat $=11$, and starch $=10$ (all in $\mathrm{g} / \mathrm{kg}$ of $\mathrm{DM}$ ), and $\mathrm{GE}=17.6 \mathrm{MJ} / \mathrm{kg}$ of DM. The chemical composition of the dietary treatments calculated from the chemical analyses and proportion of each diet ingredient are presented in Table 1.

Table 1. Chemical composition of corn silages and diets, and fermentation profile of corn silages differing in maturity at harvest

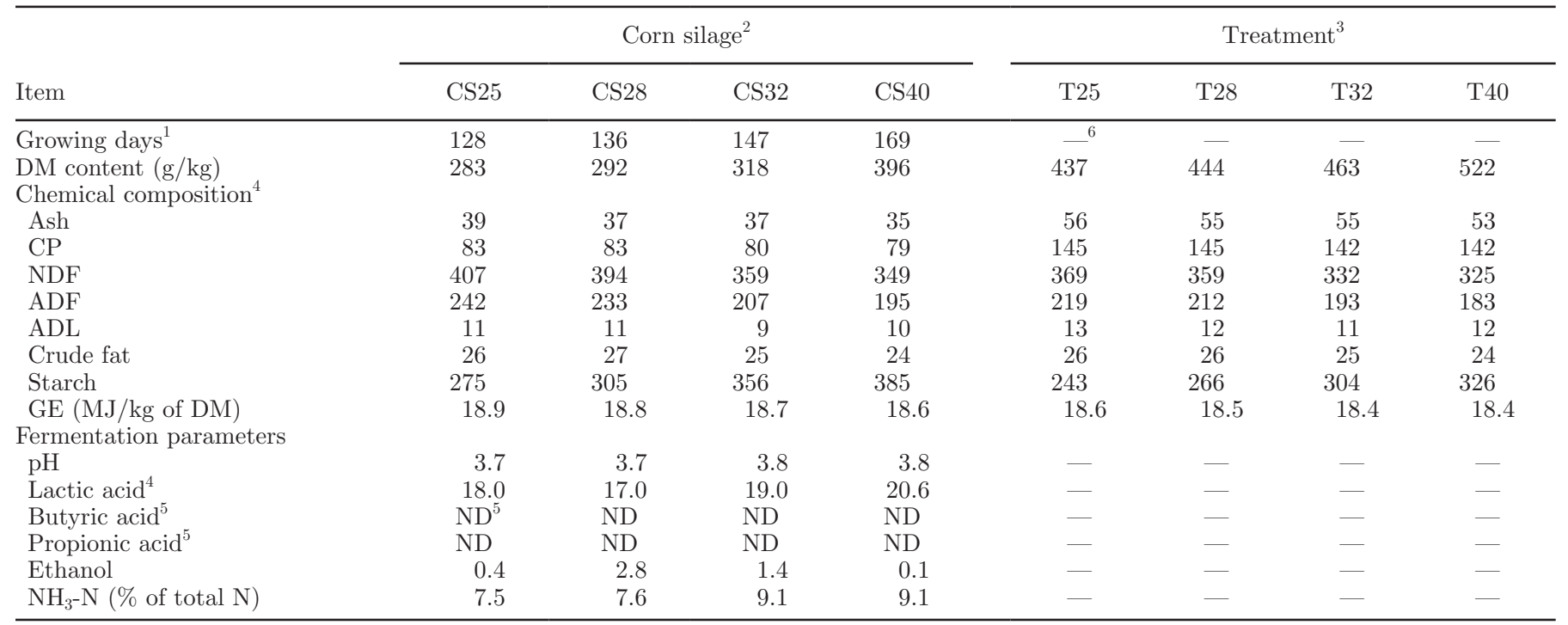

\footnotetext{
${ }^{1}$ Number of days from planting until harvesting of the whole plant for ensiling. T25, T28, T32, and T40 contained CS25, CS28, CS32, and CS40, respectively.

${ }^{4}$ Values in grams per kilogram of DM, unless stated otherwise.

${ }^{5}$ Both butyric and propionic acids were not detected in the corn silage.

${ }^{6}$ Not applicable.
}

${ }^{2}$ Whole-plant corn was harvested at a DM content of 25, 28, 32, and 40\% for CS25, CS28, CS32, and CS40, respectively.

${ }^{3}$ Treatments had roughage-to-concentrate ratio of 80:20 (DM basis). Roughage consisted of (DM basis) $75 \%$ corn silage and 5\% wheat straw. 
Corn silage and wheat straw mixtures were prepared twice weekly using a self-propelled mixer wagon (Strautmann Verti-Mix 500, Bad Laer, Germany) equipped with a cutter loader system and an electronic weighing unit and stored in a cooling unit $\left(6^{\circ} \mathrm{C}\right)$ before feeding. The daily rations were offered individually in 2 equal meals at 0600 and $1600 \mathrm{~h}$, with any feed refusal being removed before feeding and recorded. The roughage portion and concentrate (which was in the form of meal) were thoroughly mixed manually when fed.

Five days before the start of the adaptation period cows from the same block were housed in the free-stall barn in a group to acclimatize gradually to an increased level of inclusion of nonexperimental corn silage and a decreased level of concentrate in the diet (compared with the regular dairy ration they received previously), which was considered a pre-adaptation period. After this period, dietary treatments were introduced and cows were individually housed in tie-stalls for a $12-\mathrm{d}$ adaptation period. During the first $8 \mathrm{~d}$ of the adaptation period, cows were fed ad libitum. From d 9 onward, feed intake was restricted per block to $95 \%$ of the ad libitum feed intake of the animal with the smallest DMI during the 5 preceding days as described previously by van Zijderveld et al. (2011), but at all times a minimum DMI of at least $80 \%$ of the ad libitum intake of cows with the greatest DMI within block was ensured. Diet allowance was restricted to reduce variation in feed intake between animals per block and to ensure complete consumption of the ration during the measurement days. Variation in feed intake level affects retention time of digesta (and consequently extent of fermentation) and VFA profile in the rumen, generally resulting in an inverse relationship between feed intake level and $\mathrm{CH}_{4}$ production per unit feed or animal product (Hammond et al., 2013). By restricting feed intake, the methane reducing potential of CS maturity could be evaluated.

Following the adaptation period, cows were individually housed in 1 of 4 identical climate-controlled respiration chambers (CRC) for $\mathrm{CH}_{4}$ measurements and measurements of energy and $\mathrm{N}$ balance. Cow-treatment combinations were randomly assigned to 1 of the 4 CRC. Cows entered the chambers on d 13 at $1500 \mathrm{~h}$ and left the chambers on d 17 at $0900 \mathrm{~h}$. Detailed information on the technical aspects of the chamber design, calibrations, and gas analyses has been reported by van Gastelen et al. (2015). Briefly, in each CRC (volume $35 \mathrm{~m}^{3}$ ) relative humidity was maintained at $70 \%$ and temperature at $16^{\circ} \mathrm{C}$. The ventilation rate was $42 \mathrm{~m}^{3} / \mathrm{h}$ per compartment, and inlet and exhaust air of each compartment was sampled at 10-min intervals. Gas concentrations and ventilation rates were corrected for pressure, temperature, and humidity to arrive at standard temperature pressure dew point volumes of inlet and exhaust air. Cows were exposed to $16 \mathrm{~h}$ of light per day and within the CRC, cows were able to see and hear each other to prevent social isolation. Cows in the chamber were tethered in individual stalls with slatted floor fitted for collection of manure (feces and urine mixture) output. Staff entered each CRC twice daily at 0600 and $1600 \mathrm{~h}$ for approximately $30 \mathrm{~min}$ for milking, feeding, and taking fecal grab samples. Animals had unrestricted access to drinking water during the entire experimental period.

\section{Sample Collection and Measurements}

Samples of ruminal fluid from rumen cannulated cows were collected on d 10 and 11 of the adaptation period to measure $\mathrm{pH}$, and determine VFA and ammonia concentrations. Rumen fluid samples (approximately 250 $\mathrm{mL}$ ) were collected at $0 \mathrm{~h}$ (premorning feeding), and 1 , $2,3,4,6,8$, and $10 \mathrm{~h}$ postmorning feeding on both days using the method described by Hatew et al. (2015). The $\mathrm{pH}$ of the sample was immediately measured using a portable pH meter (Hanna Instruments Model HI 9024, IJsselstein, the Netherlands). Then, 2 subsamples were collected. The first sample was acidified with equal volume of $0.85 \%$ ortho-phosphoric acid containing 19.68 $\mathrm{m} M$ isocaproic acid as internal standard, and stored at $-20^{\circ} \mathrm{C}$ until analyses for VFA by using gas chromatography (Fisons HRGC MEGA2, Milan, Italy), whereas the second sample was mixed with an equal volume of $10 \%$ trichloroacetic acid and stored at $-20^{\circ} \mathrm{C}$ pending analysis for ammonia.

For DM content determination of the feeds, samples from CS were collected upon feed preparation and dried at $60^{\circ} \mathrm{C}$ in a forced-air oven at least for $48 \mathrm{~h}$. Samples of concentrate and wheat straw were collected once weekly and analyzed for DM as mentioned above. For the purpose of other chemical analyses, samples from each CS offered in the CRC were collected each time the feeds were prepared and stored at $-20^{\circ} \mathrm{C}$. These samples were later thawed and 2 subsamples were taken. The first subsample was used for in situ incubation, whereas the second one was dried in a forced-air oven at $60^{\circ} \mathrm{C}$ waiting for chemical analyses. Orts, when present during the period in the CRC, were collected and pooled per cow. Daily amount of orts present during the measurement period was $0.7 \mathrm{~kg} \pm 0.86$ (mean $\pm \mathrm{SD}$; DM basis).

To determine the total-tract apparent digestibility of DM, OM, N, crude fat, starch, NDF, and GE, cows were offered chromium oxide incorporated in the concentrate (1.5 g per $\mathrm{kg}$ of concentrate DM), which was 
used as an indigestible marker (Warner et al., 2015). Fecal grab samples were collected daily in CRC during milking, mixed and pooled per cow and a subsample stored at $-20^{\circ} \mathrm{C}$.

Gaseous exchange measurements $\left(\mathrm{O}_{2}\right.$ consumption and $\mathrm{CO}_{2}$ production) were initiated after the cows entered the CRC and recorded for each measurement period and each individual cow following the detailed procedures described by van Gastelen et al. (2015). Respiration gases and condensed water from the CRC were collected and stored at $4^{\circ} \mathrm{C}$ pending analyses for N. For energy (expressed per unit metabolic BW) and $\mathrm{N}$ balance estimation, stainless steel gutter pans were fixed in the gutter behind each cow. At the end of each measurement period in CRC (i.e., d 17 after 0900 h), manure (feces and urine mixture) output of each cow was quantitatively collected and transferred into a large container and total weight was recorded. After thorough mixing, 2 samples (approximately $500 \mathrm{~mL}$ ) were taken and stored at $-20^{\circ} \mathrm{C}$ pending analyses for energy and $\mathrm{N}$ contents. Determination of the amount and energy content of the manure and direct measurement of $\mathrm{CH}_{4}$ emission allowed estimating the ME intake, and simultaneous measurement of gaseous exchange allowed to indirectly estimate heat production according to the relationship previously described (Brouwer, 1965). Nitrogen lost in the form of ammonia that may result from mixing of feces and urine was captured and quantified as described by Hatew et al. (2015).

Feed intake, milk production, and $\mathrm{CH}_{4}$ emission parameters recorded during the last $3 \mathrm{~d}$ of each period in CRC were used for statistical analyses. For calculation of energy and $\mathrm{N}$ balance, average DMI per cow was computed for d 13 (0800 h of d 13) to d 16 (0800 h of d 17) of each period based on daily records of total diet offered and refusals for each cow. Cows were weighed immediately after entering and just before leaving the CRC. The gas measurements during opening of the CRC for milking and feeding purpose were excluded from data analyses.

Milk samples from a.m. and p.m. milking were collected for a total of 8 milkings (starting from d 13 afternoon to d 17 morning) of each period and analyzed for fat, protein, lactose, and urea. Average daily concentrations of milk components were calculated after adjusting for milk yield of each milking. For energy and $\mathrm{N}$ balance determination, milk yield in CRC was recorded and a milk sample at each milking $(5 \mathrm{~g} / \mathrm{kg}$ of milk yield) was collected, pooled per cow, and stored at $-20^{\circ} \mathrm{C}$ pending analyses for energy and $\mathrm{N}$ contents. In addition, a representative sample $(5 \mathrm{~g} / \mathrm{kg}$ milk yield) for each cow was obtained for milk FA composition determination according to the method described by van Gastelen et al. (2015).

\section{Estimation of In Situ Ruminal Degradability}

In situ ruminal degradation characteristics of the CS were determined in a separate experiment using 3 lactating dairy cows fitted with ruminal cannulas. Cows were fed ad libitum a mixed diet composed of (DM basis) $39 \%$ corn silage and $61 \%$ grass silage and a concentrate according to milk production up to a maximum of $7 \mathrm{~kg} / \mathrm{d}$. The cows were on average $217 \pm$ 0.6 (mean $\pm \mathrm{SD}$ ) DIM and producing $27.4 \pm 1.7 \mathrm{~kg} / \mathrm{d}$ of milk. A pooled subsample of each CS was obtained from samples collected during the $\mathrm{CH}_{4}$ measurement periods in CRC (d 13 to 17$)$ and stored frozen $\left(-20^{\circ} \mathrm{C}\right)$. Frozen samples of each CS were cut using a food cutter (FEUMA FGC 10-2, Gößnitz, Germany) for $1 \mathrm{~min}$. Then, approximately $5.0 \mathrm{~g}$ (DM basis) of each silage was weighed into 4 nylon bags per incubation time for each cow. Bags were incubated in the rumen of each of the 3 cows for $3,6,12,24,48,96$, and $336 \mathrm{~h}$ according to the all-in all-out procedure or "complete exchange" method (Paine et al., 1982). Incubations started at the same time $(0800 \mathrm{~h})$ for all time points and incubations were completed within 3 weeks.

Upon removal of bags from the rumen, bags were washed using a modified rising method (de Jonge et al., 2013). Briefly, bags were placed in a glass vessel $(19 \mathrm{~cm}$ i.d., $7 \mathrm{~cm}$ height; 2 bags per vessel) containing $500 \mathrm{~mL}$ of buffer solution $\left(12.2 \mathrm{~g} / \mathrm{L} \mathrm{NaH}_{2} \mathrm{PO}_{4} \cdot \mathrm{H}_{2} \mathrm{O}\right.$ and $8.9 \mathrm{~g} / \mathrm{L}$ $\mathrm{Na}_{2} \mathrm{~B}_{4} \mathrm{O}_{7} \cdot 10 \mathrm{H}_{2} \mathrm{O}$, adjusted to $\mathrm{pH} 6.2$ with hydrochloric acid). The vessels were placed in a mechanical shaker (Julabo SW-20c, Julabo GmhB Seelbach, Germany) and were shaken for $60 \mathrm{~min}$ at 40 strokes per minute at room temperature. Rinsed nylon bags were dried at $60^{\circ} \mathrm{C}$ in a forced-air oven and weighed. Dried residues from 4 bags for each cow, treatment, and incubation time combination were pooled to one sample, ground, and analyzed for DM, ash, starch, and NDF contents.

Data of in situ ruminal disappearance of starch, OM and NDF were used to determine rumen degradation characteristics of starch, OM, and NDF of each CS using an exponential first-order model (Robinson et al., 1986), viz. proportion of residue present at time $t=$ $\mathrm{U}+\mathrm{D} \times \mathrm{e}^{(-\mathrm{kd} \times \mathrm{t})}$. The nonlinear procedure of SAS was used to estimate the parameter values, with the potentially degradable fraction (D), undegradable fraction $(\mathbf{U})$, and the fractional rate of degradation of the $\mathrm{D}$ fraction $\left(\mathbf{k}_{\mathbf{d}}\right)$ constrained to be positive. The washout fraction (W) which is assumed to be rapidly degradable was calculated as $1-\mathrm{D}-\mathrm{U}$. It is assumed that the $\mathrm{U}$ and $\mathrm{W}$ fractions were zero for starch and NDF, respectively, and no lag time was included in the model for NDF degradation. Effective rumen degradability (ERD) was calculated as described by Ørskov and McDonald (1979) assuming a fractional rumen outflow 
rate of $0.045,0.060$, and $0.020 / \mathrm{h}$ for $\mathrm{OM}$, starch, and $\mathrm{NDF}$, respectively.

\section{Sample Preparation and Analytical Procedures}

Prior to analyses, samples were prepared as described by Hatew et al. (2015) except that samples were dried at $60^{\circ} \mathrm{C}$ in a forced-air oven. Analyses of feeds, orts, feces, and manure, and determination of ruminal VFA concentration and milk composition were carried out according to the methods previously reported by Hatew et al. (2015), except for NDF, ADF, and ADL, which were analyzed using an Ankom ${ }^{2000}$ fiber analyzer (Ankom Technology, Macedon, NY).

The fermentation characteristics of CS were measured on aliquots obtained with maceration. Briefly, $30 \mathrm{~g}$ of CS sample was weighed into a stomacher (blending) bag, diluted with $270 \mathrm{~mL}$ of distilled water and mixed vigorously for $5 \mathrm{~min}$. The $\mathrm{pH}$ of the aliquots was measured immediately using a bench top $\mathrm{pH}$ meter (Hanna Instruments pH 300 GLP, Amorim Póvoa de Varzim, Portugal). About $30 \mathrm{~mL}$ of the aliquot sample was centrifuged at $25,000 \times g$ for $10 \mathrm{~min}$ at $4^{\circ} \mathrm{C}$, and 2 samples from the supernatants were collected. The first sample was acidified with equal volume of $10 \%$ trichloroacetic acid and the second one with $0.85 \%$ ortho-phosphoric acid for ammonia and VFA analyses, respectively, and stored at $-20^{\circ} \mathrm{C}$. The VFA concentration was analyzed using gas chromatography (Fisons HRGC MEGA2, Milan, Italy), and ammonia concentration was determined by a colorimetric method (Scheiner, 1976). Lactic acid in the supernatant was analyzed by HPLC and ethanol determined enzymatically according to the BoehringerMannheim (1989) method.

Milk FA composition was analyzed through gas chromatography as described in detail by van Gastelen et al. (2015). Results of FA were expressed as grams per $100 \mathrm{~g}$ of total FA.

\section{Statistical Analyses}

All measurements from 3 cows in CRC were excluded from the statistical analyses. One cow (receiving diet T32) was removed due to mastitis and 2 cows (receiving diet T40) were removed because of large feed refusals in combination with an irregular pattern of feed intake and milk yield. Prior to analyses, data for intake, digestibility, milk parameters, $\mathrm{CH}_{4}$ emission parameters, energy, and $\mathrm{N}$ balance were averaged per experimental period and cow. Data were checked for normality using the univariate procedure of SAS, and data were transformed when appropriate using a natural logarithm function and exponential function to back-transform the least squares means and standard error of the means.

All data on feed intake, milk yield and composition, apparent total-tract digestibility, $\mathrm{CH}_{4}$ parameters, and energy and $\mathrm{N}$ balance were analyzed as a completely randomized block design using the MIXED procedure in SAS (SAS Institute Inc., 2010). The model included the fixed effect of treatment (DM content of CS at harvest) and a random effect of block. Each block of 4 cows was completed within one experimental period; thus, period effect was completely confounded with block effect. Similarly, data on in situ rumen degradation of the corn silages were analyzed using the MIXED procedure in SAS with treatment as fixed effect and cow as random effect. The Kenward-Roger method was used to calculate the denominator degree of freedom. Autoregressive 1, variance component, compound symmetry, and unstructured covariance structures were tested for each analyses and the covariance structure with the lowest overall Akaike's information criterion values (i.e., variance component) was selected.

Data for ruminal $\mathrm{pH}$, ammonia, and VFA concentrations were averaged per time point per cow and subjected to repeated-measures ANOVA to take repeated samples within the same animal into account. This model included cow and block as random effects, and treatment, time of sampling and the interaction of treatment and time of sampling as fixed effects. Because of the inherent unbalanced sampling-time interval, spatial power variance component was used as the covariance structure of choice to account for within-cow variation.

Orthogonal polynomial contrasts (linear and quadratic) were used to examine the effects of treatment (DM content of whole-plant corn at harvest) on response variables. Due to unequally spaced treatments, polynomial coefficients were generated by using the orthogonal polynomial (ORPOL) function in IML (interactive matrix language) procedure of SAS.

All results are reported as least squares means, and significance of linear and quadratic treatment effects was declared at $P \leq 0.05$ and trends at $0.05<P \leq$ 0.10 .

\section{RESULTS}

\section{Chemical Composition of Silages and Diets}

As whole-plant corn maturity at harvest progressed, CS starch content increased from 275 to $385 \mathrm{~g} / \mathrm{kg}$ of DM (CS25 vs. CS40), coinciding with a reduction of NDF content (from 407 to $349 \mathrm{~g} / \mathrm{kg}$ of DM) and ADF content (from 242 to $195 \mathrm{~g} / \mathrm{kg}$ of DM; Table 1). The $\mathrm{ADL}, \mathrm{CP}$, crude fat, and GE contents of $\mathrm{CS}$ varied 
within a rather narrow range only, and volatile fermentation products in CS were minor. The same pattern of change for starch, NDF, and ADF contents occurred for dietary treatments. The silages were of good quality as reflected by low $\mathrm{pH}$, small concentration of $\mathrm{N}^{-\mathrm{NH}_{3}}$, and no detectable presence of butyric and propionic acids. Virtually no discoloration or surface spoilage was visible in the silos.

\section{In Situ Ruminal Degradation of Corn Silages}

The ruminal fractional rate of degradation of starch $(P=0.006)$ and NDF $(P=0.040)$ decreased linearly with increased maturity of whole-plant corn at harvest (Table 2). For OM, the D-fraction increased $(P=$ $0.001)$ and the $\mathrm{k}_{\mathrm{d}}$ tended to decrease $(P=0.092)$ quadratically with maturity. The estimated ERD of starch decreased linearly $(P<0.001)$, and the ERD of OM $(P$ $=0.001)$ and $\mathrm{NDF}(P=0.006)$ decreased quadratically with maturity. The ERD of starch, OM, and NDF were reduced by 13,8 , and $20 \%$, respectively, with advanced maturity.

\section{Ruminal Fermentation Characteristics of Diets}

Rumen $\mathrm{pH}$, total VFA concentration, VFA molar proportions, and ammonia concentration were not affected by dietary treatments, except for a tendency for the molar proportion of propionate to decrease quadratically $(P=0.056)$ and the ratio of acetate to propionate to increase linearly $(P=0.089)$ with advancing maturity of whole-plant corn at harvest (Table 3 ). All rumen variables were affected by time of rumen sampling $(P<$ 0.001; data not shown), but no treatment and time of sampling interactions were observed except for butyrate $(P=0.008$; data not shown $)$. In general, rumen $\mathrm{pH}$ initially decreased after morning feeding and increased again several hours later, whereas VFA concentration showed the opposite pattern (data not shown).

\section{Animal Performance}

Intake of DM, OM, CP, and GE were unaffected by maturity of whole-plant corn at harvest (Table 4). Starch intake increased quadratically $(P<0.001)$, but NDF $(P<0.001)$, ADF $(P<0.001)$, and crude fat $(P=0.001)$ intake decreased linearly with maturity. Apparent total-tract digestibility of $\mathrm{DM}(P=0.002)$, OM $(P=0.003), \mathrm{CP}(P=0.001), \mathrm{NDF}(P<0.001)$, crude fat $(P<0.001)$, starch $(P<0.001)$, and GE $(P$ $=0.002)$ decreased linearly with maturity. Milk yield, FPCM, and milk fat, protein, lactose, and urea contents, and milk fat, protein, and lactose yields were all unaffected by maturity of whole-plant corn at harvest (Table 5).

\section{Milk Fatty Acid Composition}

The concentration of C4:0 in milk fat decreased linearly $(P=0.019)$, whereas concentration of some medium-chain milk FA (C10:0, C11:0, and C13:0) increased linearly $(P \leq 0.032)$ with maturity of whole-plant corn at harvest (Table 6). Concentration of C16:0 decreased quadratically $(P=0.003)$, and $\mathrm{C} 16: 1$ trans -9 , iso $\mathrm{C} 17: 0$,

Table 2. In situ rumen degradation characteristics of corn silages differing in maturity at harvest

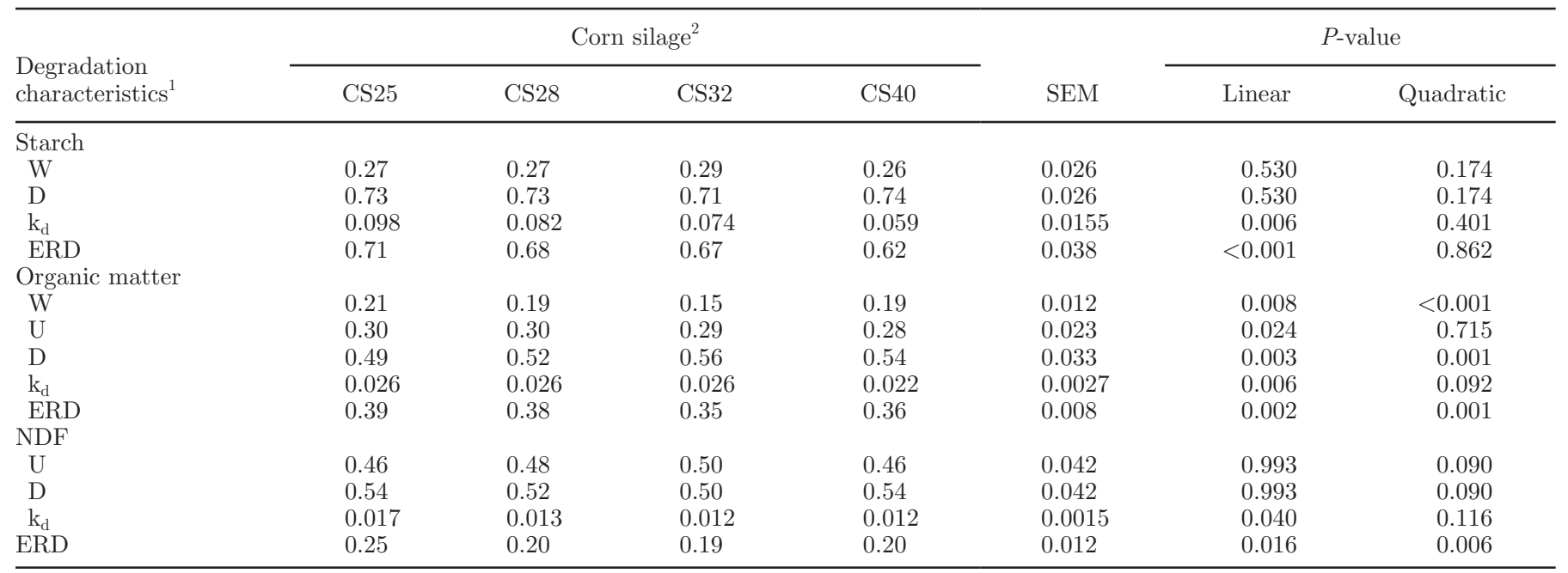

${ }^{1} \mathrm{~W}=$ washable fraction $(\mathrm{g} / \mathrm{g})$ and assumed to be zero for NDF; D = potentially degradable fraction (g/g); U = undegradable fraction (g/g) and assumed to be zero for starch; $\mathrm{k}_{\mathrm{d}}=$ fractional degradation rate constant of the potentially degradable fraction $(/ \mathrm{h}) ; \mathrm{ERD}=\mathrm{effective}$ rumen degradability $(\mathrm{g} / \mathrm{g})$.

${ }^{2}$ Whole-plant corn was harvested at a DM content of 25, 28, 32, and 40\% for CS25, CS28, CS30, and CS40, respectively. 
Table 3. Rumen fluid characteristics of lactating dairy cows fed diets based on corn silage differing in maturity at harvest

\begin{tabular}{|c|c|c|c|c|c|c|c|}
\hline Item & \multicolumn{4}{|c|}{ Treatment $^{1}$} & SEM & \multicolumn{2}{|c|}{$P$-value } \\
\hline Rumen pH & 6.49 & 6.43 & 6.56 & 6.44 & 0.032 & 0.631 & 0.197 \\
\hline \multicolumn{8}{|l|}{ VFA $(\mathrm{mol} / 100 \mathrm{~mol})$} \\
\hline Acetate (A) & 63.8 & 65.2 & 63.9 & 65.1 & 0.50 & 0.291 & 0.800 \\
\hline Propionate $(\mathrm{P})$ & 20.2 & 18.7 & 17.9 & 18.5 & 0.51 & 0.096 & 0.056 \\
\hline Iso-acids ${ }^{2}$ & 2.5 & 2.8 & 2.7 & 3.1 & 0.20 & 0.106 & 0.803 \\
\hline $\mathrm{A}: \mathrm{P}$ & 3.2 & 3.5 & 3.6 & 3.6 & 0.09 & 0.089 & 0.169 \\
\hline Ammonia $(\mathrm{mg} / \mathrm{L})$ & 132.3 & 137.7 & 125.7 & 97.2 & 13.06 & 0.131 & 0.274 \\
\hline
\end{tabular}

${ }^{1}$ Treatments had roughage-to-concentrate ratio of 80:20 (DM basis). Roughage consisted of (DM basis) $75 \%$ corn silage and $5 \%$ wheat straw. T25, T28, T32, and T40 contained corn silage made from whole-plant corn harvested at a DM content of $25,28,32$, and $40 \%$, respectively.

${ }^{2}$ Iso-acids $=$ isobutyrate + isovalerate.

C18:1 cis-9, and C18:1 cis-13 increased quadratically $(P \leq 0.040)$. Concentration of $18: 2 \mathrm{n}-6$ increased linearly $(P=0049)$ and the inverse was observed for C18:3n-3 $(P=0.002)$. The concentration of C18:3n-6 and C20:5n-3 decreased quadratically $(P \leq 0.037)$. Total SFA decreased $(P=0.030)$ and MUFA increased $(P$ $=0.034$ ) quadratically with, respectively, the highest and lowest concentration with T28, and the ratio of n-6:n-3 increased linearly $(P<0.001)$ with maturity of whole-plant corn at harvest.

\section{Methane Production, and Energy and N Balance}

Daily $\mathrm{CH}_{4}$ output and $\mathrm{CH}_{4}$ production relative to DMI decreased linearly $(P \leq 0.020)$, and $\mathrm{CH}_{4}$ energy loss as a fraction of GE intake (GEI) tended to decrease quadratically $(P=0.051)$ with increasing maturity of whole-plant corn at harvest (Table 7). Irrespective of unit of expression, cows fed on T28 produced numerically higher $\mathrm{CH}_{4}$ as compared with other treatments. Methane emission intensity $\left(\mathrm{CH}_{4}\right.$ per unit of FPCM) tended to decrease linearly $(P=0.058)$ with maturity and was lower for T40 (mean $=12.1 \mathrm{~g} / \mathrm{kg}$ of FPCM) compared with other treatments (mean $=13.2 \mathrm{~g} / \mathrm{kg}$ of FPCM). Similarly, $\mathrm{CH}_{4}$ produced as a proportion of OM digested tended to decrease linearly $(P=0.054)$ with maturity of whole-plant corn at harvest.

Gross energy intake and manure energy output expressed per kilogram of $\mathrm{BW}^{0.75}$ per day tended to increase quadratically $(P=0.099$ and $P=0.072$, respec-

Table 4. Intake and apparent total-tract digestibility of nutrients in lactating dairy cows fed diets based on corn silage differing in maturity at harvest

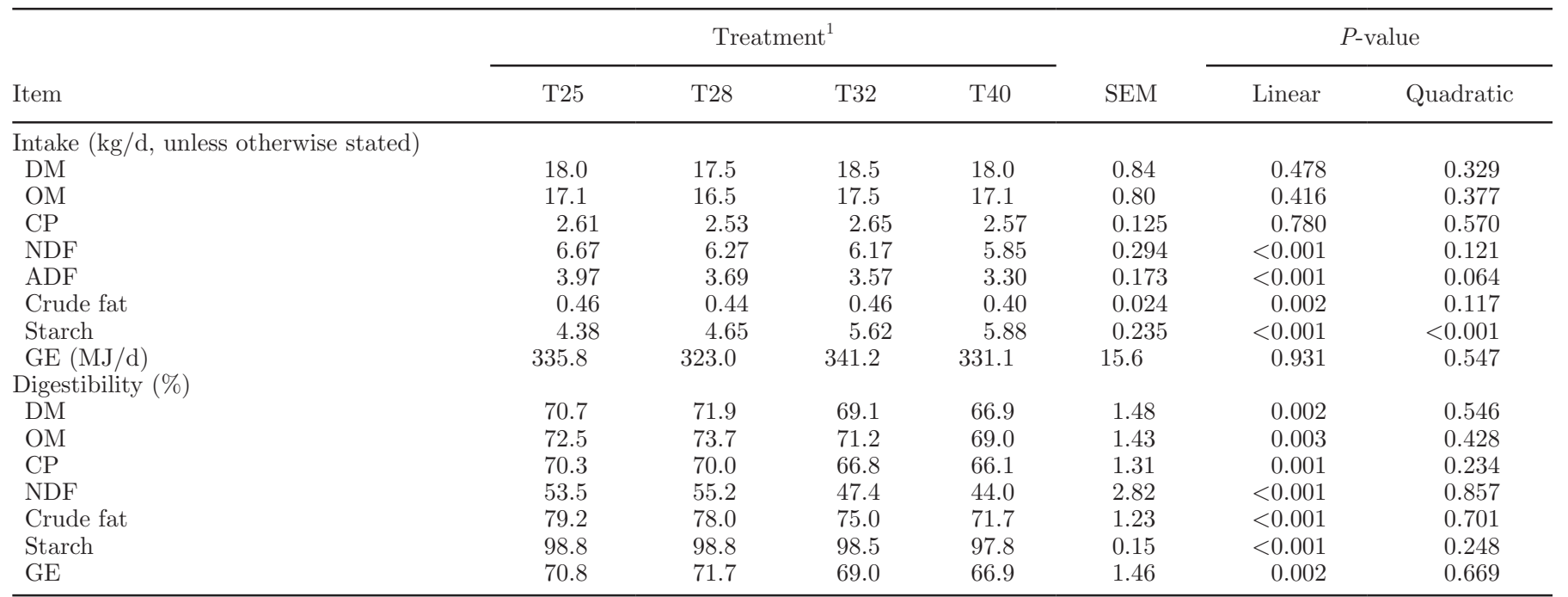

${ }^{1}$ Treatments had roughage-to-concentrate ratio of 80:20 (DM basis). Roughage consisted of (DM basis) $75 \%$ corn silage and $5 \%$ wheat straw. T25, T28, T32, and T40 contained corn silage made from whole-plant corn harvested at a DM content of $25,28,32$, and $40 \%$, respectively. 
tively), and energy lost as $\mathrm{CH}_{4}$ expressed per kilogram of $\mathrm{BW}^{0.75}$ per day decreased quadratically $(P=0.017)$ with maturity (Table 8). All other parameters related to the energy balance and expressed per kilogram of $\mathrm{BW}^{0.75}$ per day (i.e., ME intake, MEI:GEI ratio, heat production, energy output in milk, energy retention total, energy retention as protein, and energy retention as fat) were unaffected by maturity of whole-plant corn at harvest. Similarly, N intake, N excreted in the manure (feces plus urine mixture), $\mathrm{N}$ output in milk, and $\mathrm{N}$ balance were unaffected by maturity of whole-plant corn at harvest. No significant difference was found in $\mathrm{N}$ use efficiency (milk $\mathrm{N}$ as a fraction of dietary $\mathrm{N}$ intake; mean $=34.3 \%$ ) between treatments. For all dietary treatments, cows were in positive $\mathrm{N}$ balance (mean = $16 \mathrm{~g} / \mathrm{d})$.

\section{DISCUSSION}

The objective of this study was to evaluate the effects of increasing maturity of whole-plant corn at harvest on $\mathrm{CH}_{4}$ emission by lactating dairy cows. We hypothesized that increased whole-plant corn maturity decreases $\mathrm{CH}_{4}$ emission intensity due to an increase in starch content, a decrease in ruminal fractional rate of degradation of starch, and a decrease in fiber content, causing an enhanced postruminal starch supply and a shift in the profile of rumen VFA production toward more propionate and less acetate. In line with our hypothesis (except for a shift in VFA profile), $\mathrm{CH}_{4}$ emission was lower with advanced maturity irrespective of the unit of expression used. Linear trends for a change from 25 to $40 \%$ DM in whole-plant corn at harvest indicate $-9.9,-8.0,-6.6$, and $-7.1 \% \mathrm{CH}_{4}$ when expressed per kilogram of DMI, per kilogram of FPCM, per kilogram of OM digested, and as fraction of GEI, respectively. This corresponds to $-0.148,-0.071$, and $-0.142 \mathrm{~g}$ of $\mathrm{CH}_{4}$ per $\mathrm{kg}$ of DMI, per kg of FPCM, and per kilogram of digested OM, respectively, and -0.031 as fraction of GEI, per percent unit increase of DM content of wholeplant corn at harvest. In agreement with other studies (Johnson et al., 1999; Phipps et al., 2000; Fernandez et al., 2004), harvesting whole-plant corn at a late stage of maturity markedly increased starch content, and decreased NDF and ADF content of CS at feeding.

In the present study, corn silages were made from a single corn variety and from one field. The corn silage was supplemented with straw and one type of concentrate with low starch content, and the CS comprised the major part of the total diet DM (75\%) and supplied almost all the dietary starch. This enabled us to investigate the potential of increased maturity of whole-plant corn at harvest as a $\mathrm{CH}_{4}$ mitigation strategy without potential confounding effects of DMI, concentrate composition, and starch not originating from CS. The DM content of CS at feeding out from the silos ranged from 283 (CS25) to 396 (CS40) $\mathrm{g} / \mathrm{kg}$. The difference in the DM contents between CS25 and CS28 at feeding was smaller (283 vs. $292 \mathrm{~g} / \mathrm{kg}$; CS25 vs. CS28) than the difference in the DM content at harvest (251 vs. $277 \mathrm{~g} /$ $\mathrm{kg}$; CS25 vs. CS28) due to losses of moisture as seepage or effluent squeezed from the silo. Although the differences in DM content between these 2 silages at feeding were minor, the higher starch content, the lower NDF content, and the slower fractional rate of degradation of starch of CS28 compared with CS25 showed it was a more mature plant at harvest, indicating that the aim of the present study to create a range of contrasting CS was achieved. Currently, a recommended harvest practice is at DM content between 30 and $35 \%$ of the

Table 5. Milk yield and composition of dairy cows fed diets based on corn silage differing in maturity at harvest

\begin{tabular}{|c|c|c|c|c|c|c|c|}
\hline Milk variable & \multicolumn{4}{|c|}{ Treatment $^{1}$} & SEM & \multicolumn{2}{|c|}{$P$-value } \\
\hline \multicolumn{8}{|l|}{ Yield (kg/d) } \\
\hline $\mathrm{FPCM}^{2}$ & 30.2 & 30.0 & 29.7 & 30.1 & 1.57 & 0.962 & 0.614 \\
\hline Fat & 1.22 & 1.27 & 1.24 & 1.29 & 0.069 & 0.325 & 0.994 \\
\hline Protein & 0.95 & 0.91 & 0.94 & 0.91 & 0.049 & 0.392 & 0.823 \\
\hline Fat & 40.1 & 44.3 & 43.3 & 45.4 & 2.00 & 0.110 & 0.500 \\
\hline Protein & 31.1 & 31.5 & 32.7 & 32.3 & 0.88 & 0.313 & 0.375 \\
\hline Lactose & 47.7 & 48.7 & 47.8 & 47.2 & 0.47 & 0.160 & 0.223 \\
\hline Urea $(\mathrm{mg} / \mathrm{dL})$ & 20.1 & 20.2 & 17.5 & 18.1 & 1.56 & 0.196 & 0.403 \\
\hline
\end{tabular}

${ }^{1}$ Treatments had roughage-to-concentrate ratio of 80:20 (DM basis). Roughage consisted of (DM basis) $75 \%$ corn silage and $5 \%$ wheat straw. T25, T28, T32, and T40 contained corn silage made from whole-plant corn harvested at a DM content of $25,28,32$, and $40 \%$, respectively.

${ }^{2}$ Fat- and protein-corrected milk $(\mathrm{kg} / \mathrm{d})=[0.337+0.0116 \times$ fat $(\mathrm{g} / \mathrm{kg})+0.0060 \times$ protein $(\mathrm{g} / \mathrm{kg}$ of milk $)] \times$ milk yield $(\mathrm{kg} / \mathrm{d})$.

${ }^{3}$ Values are in grams per kilogram of milk, unless stated otherwise. 
Table 6. Milk FA composition of lactating dairy cows fed diets based on corn silage differing in maturity at harvest

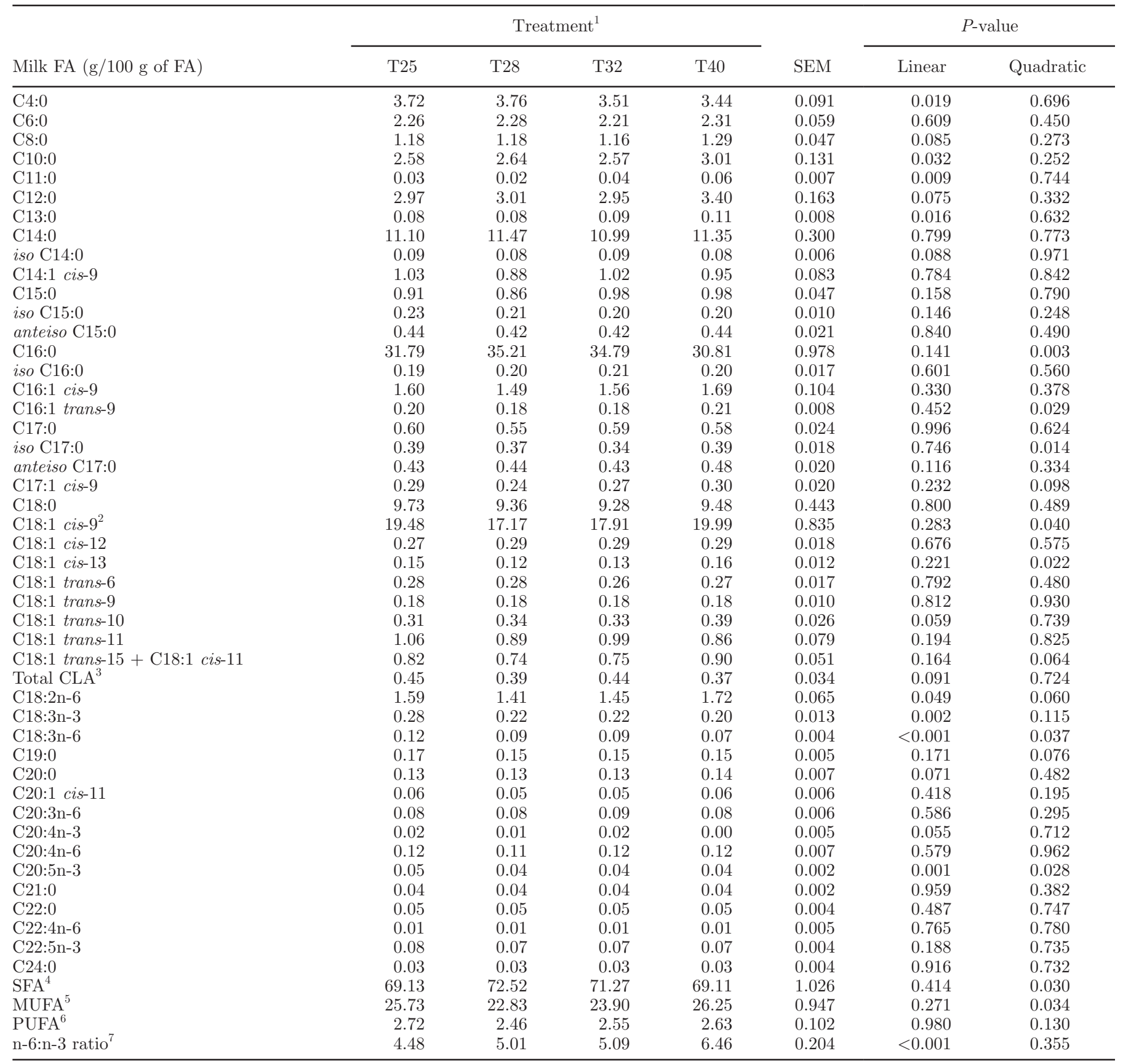

${ }^{1}$ Treatments had roughage-to-concentrate ratio of 80:20 (DM basis). Roughage consisted of (DM basis) $75 \%$ corn silage and $5 \%$ wheat straw. T25, T28, T32, and T40 contained corn silage made from whole-plant corn harvested at a DM content of $25,28,32$, and $40 \%$, respectively.

${ }^{2} \mathrm{C} 18: 1$ trans-12 represents the sum of $\mathrm{C} 18: 1$ cis-9 and C18:1 trans-12, as these 2 FA could not be separated in the analyses. The portion of C18:1 trans-12 is considered to be negligible, as this FA always present in small amounts.

${ }^{3}$ Total CLA consists mainly of C18:2 cis-9, trans- 11.

${ }^{4}$ Sum of SFA reported in this table.

${ }^{5}$ Sum of MUFA reported in this table.

${ }^{6} \mathrm{Sum}$ of PUFA reported in this table.

${ }^{7}$ Ratio between the sum of C18:2n-6, C18:3n-6, C20:3n-6, C20:4n-6, and C22:4n-6 and the sum of C18:3n-3, C20:4n-3, C20:5n-3, and C22:5n-3. 
Table 7. Methane production of lactating dairy cows fed diets based on corn silage differing in maturity at harvest

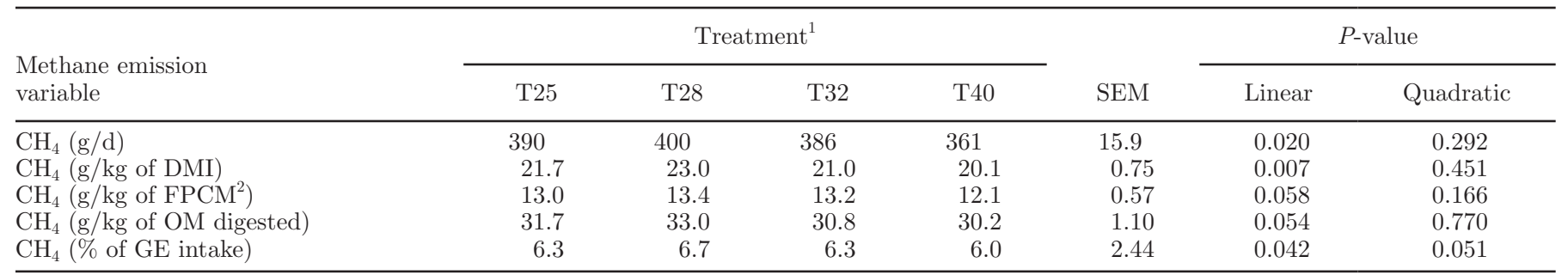

${ }^{1}$ Treatments had roughage-to-concentrate ratio of 80:20 (DM basis). Roughage consisted of (DM basis) $75 \%$ corn silage and $5 \%$ wheat straw. T25, T28, T32, and T40 contained corn silage made from whole-plant corn harvested at a DM content of $25,28,32$, and $40 \%$, respectively.

${ }^{2} \mathrm{FPCM}=$ fat- and protein-corrected milk.

corn plant (Khan et al., 2015). In the Netherlands, for example, the average starch content of corn silage is between 30 and 35\% (Bannink et al., 2011). Our results suggest that harvesting whole-plant corn at a higher maturity than current practice may have the potential to reduce enteric $\mathrm{CH}_{4}$ emissions.

\section{Ruminal Degradation and VFA Concentration}

Increased maturity of whole-plant corn from 25 to $40 \%$ DM at harvest reduced in situ effective ruminal starch degradability by $13 \%$. This agrees with the study of Andrae et al. (2001) who reported a 7 to $24 \%$ decrease of in situ disappearance of starch when comparing corn silage from 2 hybrids with DM content of 26 versus $41 \%$. The $7 \%$ decrease in ruminal starch disappearance observed in the present study (CS40 vs. CS32) is in agreement with Bal et al. (2000) who found an $8 \%$ lower ruminal starch disappearance with high (42\%) compared with low (30\%) DM content of corn silage. In the present study, the rumen fractional degradation rate of starch was reduced by $40 \%$ with advanced maturity from 25 to $40 \%$ DM. Rumen starch degradability was shown to be negatively related to corn kernel vitreousness (Correa et al., 2002). With increasing vitreous endosperm, the concentration of zein proteins increases, whereas that of glutelin proteins decreases (Phipps et al., 2000). The increase in insoluble zein proteins at the expense of the

Table 8. Energy and $\mathrm{N}$ balance of lactating dairy cows fed diets based corn silage differing in maturity at harvest

\begin{tabular}{|c|c|c|c|c|c|c|c|}
\hline \multirow[b]{2}{*}{ Energy and $\mathrm{N}$ balance variable } & \multicolumn{4}{|c|}{ Treatment $^{1}$} & \multirow[b]{2}{*}{ SEM } & \multicolumn{2}{|c|}{$P$-value } \\
\hline & $\mathrm{T} 25$ & $\mathrm{~T} 28$ & $\mathrm{~T} 32$ & $\mathrm{~T} 40$ & & Linear & Quadratic \\
\hline Metabolic BW $\left(\mathrm{kg}^{0.75}\right)$ & 124 & 119 & 117 & 122 & 3.8 & 0.821 & 0.063 \\
\hline \multicolumn{8}{|l|}{$\begin{array}{l}\text { Energy partitioning ( } \mathrm{kJ} / \mathrm{kg} \text { of } \mathrm{BW}^{0.75} \text { per day, } \\
\text { unless stated otherwise) }\end{array}$} \\
\hline GE intake (GEI) & 2,770 & 2,793 & 2,947 & 2,785 & 79.1 & 0.820 & 0.099 \\
\hline ME intake $(\mathrm{MEI})^{2}$ & 1,656 & 1,705 & 1,699 & 1,683 & 53.4 & 0.941 & 0.715 \\
\hline MEI:GEI ratio (\%) & 59.8 & 61.1 & 57.6 & 60.4 & 1.15 & 0.968 & 0.216 \\
\hline Methane production & 176 & 188 & 183 & 165 & 5.2 & 0.031 & 0.017 \\
\hline Energy in manure & 939 & 900 & 1066 & 937 & 49.1 & 0.734 & 0.072 \\
\hline Heat production & 887 & 920 & 930 & 896 & 19.3 & 0.842 & 0.142 \\
\hline Milk energy output & 753 & 791 & 781 & 769 & 26.9 & 0.893 & 0.331 \\
\hline Energy retained $(\mathrm{ER})^{3}$ & 16 & -5 & -13 & 18 & 46.6 & 0.905 & 0.581 \\
\hline ER as protein ${ }^{4}$ & 14 & 24 & 27 & 16 & 7.5 & 0.969 & 0.167 \\
\hline ER as fat & 2 & -29 & -40 & 2 & 6.8 & 0.890 & 0.395 \\
\hline \multicolumn{8}{|l|}{$\mathrm{N}$ balance (g/d, unless stated otherwise) } \\
\hline $\mathrm{N}$ intake & 426 & 417 & 426 & 419 & 17.6 & 0.684 & 0.969 \\
\hline $\mathrm{N}$ in manure & 261 & 250 & 255 & 258 & 12.4 & 0.885 & 0.215 \\
\hline $\mathrm{N}$ in milk & 149 & 143 & 145 & 142 & 7.3 & 0.294 & 0.762 \\
\hline $\mathrm{N}$ retained ${ }^{5}$ & 11 & 19 & 21 & 13 & 5.8 & 0.948 & 0.192 \\
\hline $\mathrm{N}$ use efficiency (\%) & 34.8 & 34.4 & 34.0 & 33.9 & 0.78 & 0.431 & 0.674 \\
\hline
\end{tabular}

${ }^{1}$ Treatments had roughage-to-concentrate ratio of 80:20 (DM basis). Roughage consisted of (DM basis) $75 \%$ corn silage and 5\% wheat straw. T25, T28, T32, and T40 contained corn silage made from whole-plant corn harvested at a DM content of $25,28,32$, and $40 \%$, respectively.

${ }^{2} \mathrm{ME}$ intake $=\mathrm{GE}$ intake - methane production - energy in manure (feces and urine mixture).

${ }^{3}$ Total energy retained $=$ ME intake - heat production - energy in milk.

${ }^{4}$ Energy retained as protein $=$ protein gain $(\mathrm{N} \times 6.25) \times 23.7 \mathrm{~kJ} / \mathrm{g}$ of protein.

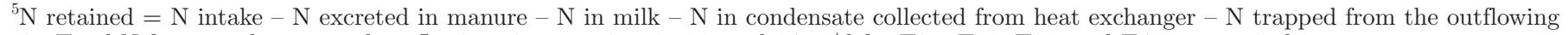
air. Total $\mathrm{N}$ from condensate and outflowing air was 5.2, 5.1, 5.2, and $6.7 \mathrm{~g} / \mathrm{d}$ for T25, T28, T32, and T40, respectively. 
soluble glutelin proteins limits accessibility of starch granules to ruminal microorganisms. Although we did not measure the vitreousness of endosperm of the corn, the in situ data confirmed that ERD of starch by rumen microorganisms decreased with increasing maturity of whole-plant corn at harvest.

The increase in starch intake (34\%) and decrease in NDF $(12 \%)$ and $\operatorname{ADF}(17 \%)$ intake with increased corn maturity did not affect ruminal $\mathrm{pH}$ and VFA concentrations. The higher starch intake was anticipated to favor propionate production at the expense of acetate (Lettat et al., 2013) because diets with high starch content are often associated with increased propionate in the rumen (Ellis et al., 2008). However, in the present experiment the molar proportion of propionate tended to decrease, and the acetate-to-propionate ratio tended to increase with maturity, possibly related to the decline in fractional rate of degradation of starch, or increased ruminal fractional passage rate relative to ruminal fractional rate of degradation. This result is largely in agreement with Fernandez et al. (2004) who also did not find differences in ruminal $\mathrm{pH}$, total VFA concentration, and VFA molar proportions (except for a tendency in propionate molar proportion) when cows were fed diets composed of $80 \%$ (DM basis) WPCS made from whole-plant corn harvested at an early (24\% DM) and late (32\% DM) stage of maturity. Johnson et al. (2002b) found greater ruminal acetate and lower propionate concentrations 2 and $6 \mathrm{~h}$ after feeding in rumen fluid of cows offered corn silage from whole-plant corn harvested at more advanced maturity (48\% DM) as compared with $34 \%$ DM, and explained the effect from decreased ruminal starch digestion rate with advanced maturity. It is important to note that we tested diets with $80 \%$ roughage in DM, including $5 \%$ wheat straw, which may have increased buffering capacity and chewing activity (Mertens, 1997), causing a lack of effect on rumen $\mathrm{pH}$. In line with our results, van Gastelen et al. (2015) also found no effect of inclusion of $80 \%$ corn silage versus $80 \%$ grass silage in the diet (DM basis) of lactating cows on molar proportion of propionate and rumen $\mathrm{pH}$.

\section{Total-Tract Digestibility and Animal Performance}

The decrease in fecal OM digestibility with increased maturity of whole-plant corn at harvest could be due to a slight decrease in starch digestibility and a large decline in NDF digestibility, which matches the decrease in digestibility reported for the stover (leaves and stem) portion of the corn plant (Tolera et al., 1998; Johnson et al., 1999). A decrease in fecal starch digestibility only became apparent with CS made from the most mature corn, which agrees qualitatively with the
98.2, 98.1, 98.2, and 96.6\% apparent starch digestion observed by Cammell et al. (2000) for a similar range of DM content of corn silage at harvest $(23,28,33$, and $38 \%$, respectively), as used in the present study. Jensen et al. (2005) also recorded a slightly decreased starch digestibility from 100 to $98 \%$ with an increase of DM content at harvest from 26 to $40 \%$. Also consistent with our result, the same authors found a significant reduction in fecal NDF digestibility with advanced maturity (from 56 to $43 \%$ vs. 54 to $44 \%$ in the present study). The increase in starch intake and expected decrease in rumen $\mathrm{pH}$ did not likely contribute to the lower NDF digestibility observed in the present study, because rumen $\mathrm{pH}$ did not differ between treatments. Moreover, the in situ data also indicated reduced fractional rate of degradation of fiber with advanced maturity. The decrease in digestibility of NDF with increasing maturity is presumably the result of an increased lignification, which interferes with enzymatic access to cell wall polysaccharides (Russell et al., 1992). Cone and Engels (1993) and Boon et al. (2005) also indicated that increased lignin content, cross-linkage of lignin with fiber, and secondary cell wall thickness with advanced maturity explains most of the variation in NDF digestibility of corn silages.

In a recent review, Khan et al. (2015) concluded that feed intake and milk yield increased with increased starch:NDF ratio at advanced maturity of corn silage, reaching an optimal level for corn silage ensiled at 300 to $350 \mathrm{~g}$ of $\mathrm{DM} / \mathrm{kg}$ and slightly declining at further maturity beyond $350 \mathrm{~g}$ of $\mathrm{DM} / \mathrm{kg}$. In the present study, no significant difference in intake was found between treatments because cows were fed restrictedly. Several studies have shown an inverse relationship between feed intake level and $\mathrm{CH}_{4}$ yield per unit feed or milk (e.g., Hammond et al., 2013). By feeding restrictedly, we evaluated the $\mathrm{CH}_{4}$ reducing potential of CS maturity without the confounding effect caused by differences in feed intake level, while acknowledging an additional effect of feed intake level on $\mathrm{CH}_{4}$ production is possible. Although in the present study the apparent total-tract digestibility of $\mathrm{OM}, \mathrm{NDF}, \mathrm{CP}$, and starch decreased with increasing maturity, dietary treatments had no effect on milk yield and milk composition. In line with this, Fernandez et al. (2004) also did not find a difference in milk yield when cows were fed diets composed of $80 \%$ WPCS (DM basis) made from corn plant harvested at an early $(24 \% \mathrm{DM})$ and late $(32 \%$ DM) stage of maturity. In contrast, reduced milk yields have been reported for DM contents higher than 35\% (Khan et al., 2015), whereas Bal et al. (1997) found an increase in milk yield when cows were fed WPCS with $35 \%$ DM compared with 30\% DM. The discrepancy between studies might be due to difference in mechanical 
processing (Johnson et al., 1999; Andrae et al., 2001), the variety of the corn investigated (Ettle et al., 2001; Johnson et al., 2002a), or differences in effects of DM content on rumen fermentation, or on OM, NDF, and starch digestibility. For instance, in the study of Bal et al. (1997) starch digestibility was 94 and $92 \%$ for corn silage made from plant harvested at 30 and $35 \%$ DM, respectively, whereas in the present study starch digestibility was the same for T28 and T32 (99\%) and only slightly different for T32 and T40 (99 vs. 98\%).

The FA content of CS was expected to be similar to that reported by Khan et al. (2011), and these affected the milk FA profile. In line with Khan et al. (2015), increased maturity of whole-plant corn at harvest from 25 to $40 \%$ DM decreased and increased the concentrations of C18:3n-3 and C18:2n-6 in milk fat, respectively, and increased the ratio of $n-6: n-3$. The change in these polyunsaturated FA in the milk matches the change in FA composition of corn plant to be expected with an increase of maturity. The C18:3n-3 is the major FA of the stover part of corn plants, whereas C18:2n-6 is the major FA of the grains or cobs (Khan et al., 2011).

\section{Methane Emission, and Energy and N Balance}

Despite the absence of differences in DMI between treatments $\mathrm{CH}_{4}$ emission per unit of DMI and per unit of FPCM, and $\mathrm{CH}_{4}$ energy loss as a fraction of GEI decreased by $9.9,8.0$, and $7.1 \%$, respectively, with a linear increase in the stage of maturity of whole-plant corn at harvest. A decreased ruminal fractional degradation rate of starch $(-40 \%)$ and increased starch intake $(+34 \%)$ with advanced maturity at harvest might have increased duodenal flow of starch (Sutton et al., 2000; Fernandez et al., 2004; Jensen et al., 2005) and hence reduced $\mathrm{CH}_{4}$ emission intensity. In addition, the marked increase in starch intake may have decreased protozoa, fibrolytic bacteria, and methanogenesis (Lettat et al., 2013). In that study using a cDNA-based quantitative PCR method, the authors reported that feeding dairy cows a $60 \%$ corn silage diet as compared with a control diet (without corn silage) reduced the richness and the diversity of the bacterial community and the protozoa number. The reduction in $\mathrm{CH}_{4}$ production was suggested to be related to the decrease in protozoa number. Using a mathematical model, Dijkstra (1994) also showed an initial increase in protozoal biomass in response to an increase in dietary starch content, but a subsequent decline again with further increase in dietary starch content as realized in the present study for the most mature CS at harvest.

Methane emission (irrespective of the unit of expression used) was numerically lower with T25 compared with T28, although ruminal fractional rate of degrada- tion of starch and NDF were higher with T25. This might be due to the higher FA content expected in CS25. With the progressive maturity of corn plants, the content of $\mathrm{C} 18: 3 \mathrm{n}-3$ in stover decreases, related to the decrease in leaf:stem ratio, and to maturation and senescence of the leaves during the grain filling period (Khan et al., 2011). In addition, C18:3n-3 was clearly present at a higher concentration in milk fat of T25 compared with other treatments. The C18:3n-3 in the milk can only originate from the diet (Khan et al., 2011). As reported in a meta-analyses of Patra (2013), the C18:3n-3 was shown to be associated with inhibition of $\mathrm{CH}_{4}$ emission to a much larger extent than C18:2n-6, the latter actually increasing in ears of corn with advanced maturity up to some $60 \mathrm{~d}$ after flowering (Khan et al., 2011), and this might be the reason for lower $\mathrm{CH}_{4}$ emission for T25 compared with T28.

In line with previous studies (Cammell et al., 2000; Phipps et al., 2000), an increased maturity had no effects on efficiency of energy utilization for milk production. Similarly, N use efficiency was not affected by dietary treatments. Starch can have a stimulating effect on rumen synthesis (Oba and Allen, 2003) and outflow of microbial protein (Oba and Allen, 2003; Fernandez et al., 2004). No effect was observed on milk protein yield in the present study, however. A high $\mathrm{N}$ utilization of $34 \%$ was achieved, related to the moderate protein content of the diet $(144 \mathrm{~g}$ of $\mathrm{CP} / \mathrm{kg}$ of $\mathrm{DM})$. If dietary CP would not have been sufficient, it may have prevented a further benefit of feeding silage with high starch content on milk yield and $\mathrm{N}$ utilization.

\section{CONCLUSIONS}

Increasing maturity of corn at harvest markedly increased starch content and decreased NDF content in CS, as well as decreased in situ ruminal fractional rate of degradation of starch, which resulted in a reduced $\mathrm{CH}_{4}$ emission irrespective of the unit of expression used (per kilogram of DMI, per kilogram of digested OM, per kilogram of FPCM, or as a fraction of GEI). Rumen VFA production profile was not changed, however, and seems unrelated to the observed differences in $\mathrm{CH}_{4}$ production. Results of the present study suggest that increasing maturity of whole-plant corn at harvest may offer an effective strategy to decrease $\mathrm{CH}_{4}$ production of dairy cows with feeding CS without negatively affecting cow performance.

\section{ACKNOWLEDGMENTS}

The authors gratefully acknowledge the Dutch Ministry of Economic Affairs (The Hague, the Netherlands), Product Board Animal Feed (Zoetermeer, the Nether- 
lands), and the Dutch Dairy Board (Zoetermeer, the Netherlands) for providing financial support for this research, and the TI Food and Nutrition (Wageningen, the Netherlands) project "Reduced methane emission of dairy cows" for providing milk FA data. We also thank S. J. J. Alferink and T. Zandstra and the staff of the experimental facilities "Carus" of Wageningen University for their assistance during the implementation of the experiment, and personnel in the laboratory of the Animal Nutrition Group of Wageningen University for their assistance in laboratory sample analyses.

\section{REFERENCES}

Andrae, J. G., C. W. Hunt, G. T. Pritchard, L. R. Kennington, J. H. Harrison, W. Kezar, and W. Mahanna. 2001. Effect of hybrid, maturity, and mechanical processing of corn silage on intake and digestibility by beef cattle. J. Anim. Sci. 79:2268-2275.

Bal, M. A., J. G. Coors, and R. D. Shaver. 1997. Impact of the maturity of corn for use as silage in the diets of dairy cows on intake, digestion, and milk production. J. Dairy Sci. 80:2497-2503.

Bal, M. A., R. D. Shaver, K. J. Shinners, J. G. Coors, J. G. Lauer, R. J. Straub, and R. G. Koegel. 2000. Stage of maturity, processing, and hybrid effects on ruminal in situ disappearance of whole-plant corn silage. Anim. Feed Sci. Technol. 86:83-94.

Bannink, A., J. France, S. Lopez, W. J. J. Gerrits, E. Kebreab, S. Tamminga, and J. Dijkstra. 2008. Modelling the implications of feeding strategy on rumen fermentation and functioning of the rumen wall. Anim. Feed Sci. Technol. 143:3-26.

Bannink, A., M. W. van Schijndel, and J. Dijkstra. 2011. A model of enteric fermentation in dairy cows to estimate methane emission for the Dutch national inventory report using the IPCC Tier 3 approach. Anim. Feed Sci. Technol. 166-167:603-618.

Boehringer-Mannheim GmbH. 1989. Biochemical Food Analyses. Ethanol. Ref. 176 290. Mannheim, Germany.

Boon, E. J. M. C., F. M. Engels, P. C. Struik, and J. W. Cone. 2005. Stem characteristics of two forage maize (Zea mays L.) cultivars varying in whole plant digestibility. I. Relevant morphological parameters. Neth. J. Agric. Sci. 53:71-85.

Brouwer, E. 1965. Report of sub-committee on constants and factors. Pages 441-443 in Energy Metabolism European Association for Animal Production. Vol. 11. K. L. Blaxter, ed. Academic Press, London, UK.

Cammell, S. B., J. D. Sutton, D. E. Beever, D. J. Humphries, and R. H. Phipps. 2000. The effect of crop maturity on the nutritional value of maize silage for lactating dairy cows 1. Energy and nitrogen utilization. J. Anim. Sci. 71:381-390.

Cone, J. W., and F. M. Engels. 1993. The influence of ageing on cell wall composition and degradability of three maize genotypes. Anim. Feed Sci. Technol. 40:331-342.

Correa, C. E. S., R. D. Shaver, M. N. Pereira, J. G. Lauer, and K. Kohn. 2002. Relationship between corn vitreousness and ruminal in situ starch degradability. J. Dairy Sci. 85:3008-3012.

CVB. 2008. CVB Table booklet feeding of ruminants. CVB series no. 43. Centraal Veevoederbureau, Lelystad, the Netherlands.

de Jonge, L. H., H. van Laar, W. H. Hendriks, and J. Dijkstra. 2013. A modified rinsing method for the determination of the $\mathrm{S}, \mathrm{W}-\mathrm{S}$ and $\mathrm{D}+\mathrm{U}$ fraction of protein and starch in feedstuff within the in situ technique. Animal 7:1289-1297.

Dijkstra, J. 1994. Simulation of the dynamics of protozoa in the rumen. Br. J. Nutr. 72:679-699.

Dijkstra, J., O. Oenema, and A. Bannink. 2011. Dietary strategies to reducing $\mathrm{N}$ excretion from cattle: Implications for methane emissions. Curr. Opin. Environ. Sustain. 3:414-422.

Ellis, J. L., J. Dijkstra, E. Kebreab, A. Bannink, N. E. Odongo, B. W. McBride, and J. France. 2008. Aspects of rumen microbiology central to mechanistic modelling of methane production in cattle. J. Agric. Sci. 146:213-233.

Ettle, T., P. Lebzien, G. Flachowsky, and F. J. Schwarz. 2001. Effect of harvest date and variety on ruminal degradability of ensiled maize grains in dairy cows. Arch. Anim. Nutr. 55:69-84.

Fernandez, I., P. Noziere, and B. Michalet-Doreau. 2004. Site and extent of starch digestion of whole-plant maize silages differing in maturity stage and chop length, in dairy cows. Livest. Prod. Sci. $89: 147-157$.

Hammond, K. J., J. L. Burke, J. P. Koolaard, S. Muetzel, C. S. Pinares-Patino, and G. C. Waghorn. 2013. Effects of feed intake on enteric methane emissions from sheep fed fresh white clover ( Trifolium repens) and perennial ryegrass (Lolium perenne) forages. Anim. Feed Sci. Technol. 179:121-132.

Hatew, B., S. C. Podesta, H. van Laar, W. F. Pellikaan, J. L. Ellis, J. Dijkstra, and A. Bannink. 2015. Effects of dietary starch content and rate of fermentation on methane production in lactating dairy cows. J. Dairy Sci. 98:486-499.

Hristov, A. N., J. Oh, J. L. Firkins, J. Dijkstra, E. Kebreab, G. Waghorn, H. P. S. Makkar, A. T. Adesogan, W. Yang, C. Lee, P. J. Gerber, B. Henderson, and J. M. Tricarico. 2013. Special topicsMitigation of methane and nitrous oxide emissions from animal operations: I. A review of enteric methane mitigation options. J. Anim. Sci. 91:5045-5069.

Jensen, C., M. R. Weisbjerg, P. Norgaard, and T. Hvelplund. 2005. Effect of maize silage maturity on site of starch and NDF digestion in lactating dairy cows. Anim. Feed Sci. Technol. 118:279-294.

Johnson, L., J. H. Harrison, C. Hunt, K. Shinners, C. G. Doggett, and D. Sapienza. 1999. Nutritive value of corn silage as affected by maturity and mechanical processing: A contemporary review. J. Dairy Sci. 82:2813-2825.

Johnson, L. M., J. H. Harrison, D. Davidson, M. Swift, W. C. Mahanna, and K. Shinners. 2002a. Corn silage management II: Effects of hybrid, maturity, and mechanical processing on digestion and energy content. J. Dairy Sci. 85:2913-2927.

Johnson, L. M., J. H. Harrison, D. Davidson, M. Swift, W. C. Mahanna, and K. Shinners. 2002b. Corn silage management III: Effects of hybrid, maturity, and processing on nitrogen metabolism and ruminal fermentation. J. Dairy Sci. 85:2928-2947.

Khan, N. A., J. W. Cone, W. F. Pellikaan, M. A. Khan, P. C. Struik, and W. H. Hendriks. 2011. Changes in fatty acid content and composition in silage maize during grain filling. J. Sci. Food Agric. 91:1041-1049.

Khan, N. A., P. Q. Yu, M. Ali, J. W. Cone, and W. H. Hendriks. 2015. Nutritive value of maize silage in relation to dairy cow performance and milk quality. J. Sci. Food Agric. 95:238-252.

Lettat, A., F. Hassanat, and C. Benchaar. 2013. Corn silage in dairy cow diets to reduce ruminal methanogenesis: Effects on the rumen metabolically active microbial communities. J. Dairy Sci. 96:5237-5248

Martin, C., D. P. Morgavi, and M. Doreau. 2010. Methane mitigation in ruminants: From microbe to the farm scale. Animal 4:351-365.

Mc Geough, E. J., P. O'Kiely, P. A. Foley, K. J. Hart, T. M. Boland, and D. A. Kenny. 2010. Methane emissions, feed intake, and performance of finishing beef cattle offered maize silages harvested at 4 different stages of maturity. J. Anim. Sci. 88:1479-1491.

Mertens, D. R. 1997. Creating a system for meeting the fiber requirements of dairy cows. J. Dairy Sci. 80:1463-1481.

Morgavi, D. P., E. Forano, C. Martin, and C. J. Newbold. 2010. Microbial ecosystem and methanogenesis in ruminants. Animal 4:1024-1036.

Oba, M., and M. S. Allen. 2003. Effects of diet fermentability on efficiency of microbial nitrogen production in lactating dairy cows. J. Dairy Sci. 86:195-207.

Ørskov, E. R., and I. McDonald. 1979. Estimation of protein degradability in the rumen from incubation measurements weighted according to rate of passage. J. Agric. Sci. 92:499-503.

Paine, C. A., R. Crawshaw, and W. P. Barber. 1982. A complete exchange method for the in sacco estimation of rumen degradability on a routine basis. Pages 177-178 in Forage Protein in Ruminant Animal Production BSAP Occasional Publ. No. 6.. D. J. Thom- 
son, D. E. Beever, and R. G. Gunn, ed. British Society of Animal Production, Midlothian, Scotland.

Patra, A. K. 2013. The effect of dietary fats on methane emissions, and its other effects on digestibility, rumen fermentation and lactation performance in cattle: a meta-analyses. Livest. Sci. 155:244-254.

Philippeau, C., and B. Michalet-Doreau. 1997. Influence of genotype and stage of maturity of maize on rate of ruminal starch degradation. Anim. Feed Sci. Technol. 68:25-35.

Phipps, R. H., J. D. Sutton, D. E. Beever, and A. K. Jones. 2000. The effect of crop maturity on the nutritional value of maize silage for lactating dairy cows 3. Food intake and milk production. J. Anim. Sci. 71:401-409.

Robinson, P. H., J. G. Fadel, and S. Tamminga. 1986. Evaluation of mathematical-models to describe neutral detergent residue in terms of its susceptibility to degradation in the rumen. Anim. Feed Sci. Technol. 15:249-271.

Russell, J. R., N. A. Irlbeck, A. R. Hallauer, and D. R. Buxton. 1992. Nutritive-value and ensiling characteristics of maize herbage as influenced by agronomic factors. Anim. Feed Sci. Technol. 38:11-24.

SAS Institute Inc. 2010. Statistical Analyses Software. SAS/STAT 9.3 User's Guide. SAS Inst. Inc., Cary, NC.

Scheiner, D. 1976. Determination of ammonia and Kjeldahl nitrogen by indophenol method. Water Res. 10:31-36.
Sutton, J. D., S. B. Cammell, R. H. Phipps, D. E. Beever, and D. J. Humphries. 2000. The effect of crop maturity on the nutritional value of maize silage for lactating dairy cows 2 . Ruminal and postruminal digestion. J. Anim. Sci. 71:391-400.

Tolera, A., F. Sundstol, and A. N. Said. 1998. The effect of stage of maturity on yield and quality of maize grain and stover. Anim. Feed Sci. Technol. 75:157-168.

van Gastelen, S., E. C. Antunes-Fernandes, K. A. Hettinga, G. Klop, S. J. J. Alferink, W. H. Hendriks, and J. Dijkstra. 2015. Enteric methane production, rumen VFA concentrations, and milk fatty acid composition in lactating Holstein-Friesian cows fed grass silage- or corn silage-based diets. J. Dairy Sci. 98:1915-1927.

van Zijderveld, S. M., W. J. J. Gerrits, J. Dijkstra, J. R. Newbold, R. B. A. Hulshof, and H. B. Perdok. 2011. Persistency of methane mitigation by dietary nitrate supplementation in dairy cows. J. Dairy Sci. 94:4028-4038.

Warner, D., S. C. Podesta, B. Hatew, G. Klop, H. van Laar, A. Bannink, and J. Dijkstra. 2015. Effect of nitrogen fertilization rate and regrowth interval of grass herbage on methane emission of zerograzing lactating dairy cows. J. Dairy Sci. 98:3383-3393. 